\title{
Statement of the ACO and AG-CPC on the Aftercare/Follow-up for Surgical Procedures of the Lower Genital Tract after the Introduction of a New Cancer Screening Guideline
}

\section{Stellungnahme von AGO und AG-CPC zur Nachsorge/Nachkontrolle von operativen Eingriffen am unteren Genitaltrakt nach Einführung der neuen Krebsfrüherkennungs-Richtlinie}

\section{(c) $(9) \Theta$}

Authors

Peter Hillemanns ${ }^{1,6}$, Clemens Tempfer ${ }^{2,6}$, Matthias W. Beckmann ${ }^{3,6}$, Volkmar Küppers ${ }^{4,7}$, Jens Quaas ${ }^{5,7}$

\section{Affiliations}

1 Medizinische Hochschule Hannover, Hannover, Germany

2 Ruhr Universität Bochum, Bochum, Germany

3 Universitätsklinikum Erlangen, Erlangen, Germany

4 Frauenarztpraxis, Zytologisches Labor, Düsseldorf, Germany

5 Sekretariat der Arbeitsgemeinschaft Zervixpathologie \& Kolposkopie, Stralsund, Germany

6 Arbeitsgemeinschaft Gynäkologische Onkologie e. V. (AGO) Organkommission Uterus, Germany

7 Arbeitsgemeinschaft Zervixpathologie \& Kolposkopie e. V. (AG-CPC), Germany

\section{Key words}

cervical cancer, organized cancer screening, follow-up, endometrial cancer, guideline

\section{Schlüsselwörter}

Gebärmutterhalskrebs, organisierte Krebsfrüherkennungsprogramme, Nachkontrolle, Endometriumkarzinom, Richtlinie

received 31.5 .2020

accepted 2.6.2020

\section{Bibliography}

DOI https://doi.org/10.1055/a-1193-5136

Geburtsh Frauenheilk 2020; 80: 809-812 @ Georg Thieme

Verlag KG Stuttgart · New York | ISSN 0016-5751
Correspondence

Prof. Dr. Peter Hillemanns

Hannover Medical School, Department of Gynaecology

and Obstetrics

Carl-Neuberg-Straße 1, 30625 Hannover, Germany

Hillemanns.Peter@mh-hannover.de

$\circledast$ Deutsche Version unter:

https://doi.org/10.1055/a-1193-5136

\section{ABSTRACT}

The new guideline on organized cancer screening programs has been in force in Germany since January 1st, 2020. The guideline has amended earlier recommendations on cytological examinations, which were previously carried out annually during screening. The guidelines-based recommendations on the appropriate follow-up for preinvasive and invasive lesions of the uterine cervix and endometrium are briefly outlined and differentiated from screening cytology and Pap/HPV cotesting as described in the guideline on organized cancer screening programs (oKFE-RL).

\section{ZUSAMMENFASSUNG}

Die neue Richtlinie für organisierte Krebsfrüherkennungsprogramme ist in Deutschland seit dem 01.01.2020 in Kraft. Die bisher im Rahmen des Screenings erfolgten jährlichen zytologischen Untersuchungen wurden durch die neue Richtlinie geändert. Die leitlinienbasierten Empfehlungen zur Nachsorge bei präinvasiven und invasiven Erkrankungen der Cervix uteri und des Endometriums werden dargestellt und von der Screeningzytologie bzw. Pap/HPV-Ko-Testung gemäß oKFERL abgegrenzt. 


\section{Introduction}

The new German cancer screening guideline (Krebsfrüherkennungs-Richtlinie, KFE-RL) and the corresponding guideline on organized screening programs (organisierte Krebsfrüherkennungsprogramme, oKFE-RL) which also includes screening for cervical carcinoma have been in force since January 1st, 2020. Previously, all women in Germany were routinely offered an annual cytological examination, carried out as part of cytological screening. The new guideline has changed this. It should be noted, among other things, that according to the oKFE-RL, cytological examinations and the determination of HPV status can no longer be carried out in women who have had a hysterectomy. This comment by the AGO Uterus and AG-CPC outlines the guidelines-based recommendations on follow-up and aftercare of preinvasive and invasive lesions of the uterine cervix and endometrium and differentiates them from screening cytology and Pap/HPV co-testing as recommended in the oKFE-RL.

\section{German Cancer Screening Guidelines}

I. The KFE-RL is a general cancer screening guideline which does not cover cervical cancer screening. It recommends (in Part B. Chapter II. Sec. 6 and 8 KFE-RL) carrying out the following gynecological examinations, depending on the age of the insured woman [1]:

a. From the age of 20 years:

- questions on patient's specific medical history,

- inspection of genital skin areas,

- bimanual gynecological examination,

- speculum examination of the cervix,

- communication of test results with subsequent appointment to discuss findings.

b. In addition, from the age of 30 years:

- palpation of the breast and of regional lymph nodes including instructions on how to perform regular self-examinations,

- inspection of the relevant skin areas.

II. The oKFE-RL (cervical cancer screening program) covers general cancer screening recommendations plus screening for cervical carcinoma and recommends carrying out the following gynecological exmainations (Chapter III. Part C. Sec. 6 oKFE-RL; [2]).

a. From the age of 20 years:

- questions on patient's specific medical history (including HPV vaccination status),

- inspection of genital skin areas,

- bimanual gynecological examination,

- speculum examination of the cervix,

- tissue sampling with samples taken from the surface of the cervix and the cervical canal usually using a spatula (surface of the cervix) and brush (cervical canal),

- fixation of tissue samples,

- communication of test results (including findings of the Pap smear) with subsequent appointment to discuss findings. b. In addition, from the age of 30 years:

- palpation of the breast and of regional lymph nodes including instructions on how to perform regular self-examinations,

- inspection of relevant skin areas.

It should be noted that patients who have a clinical examination in accordance with this guideline in the calendar year in which the examination is carried out will not be entitled to such an examination under Sec. 6 of the general cancer screening guideline (KFE-RL).

In this context, the legislature and the institutions commissioned with implementing the guidelines have stated:

1. Women who have undergone partial hysterectomy with preservation of the cervix are entitled to participate in the cervical cancer screening program.

2. If no tissue of the target organ of cervical cancer screening is anatomically visible any more, then the only billable preventive measure is screening carried out in accordance with the general cancer screening guideline (KFE-RL), i.e., without cytology or HPV-testing. Screening carried out in accordance with the cervical cancer screening program of the oKFE-RL cannot be carried out.

3. Follow-up examinations after surgery of the cervix, for example conization, which are done to confirm the success of treatment, are considered curative examinations. After treatment has been concluded, the patient can participate in the regular cervical cancer screening program again [3].

Accordingly, patients who are status post complete hysterectomy will no longer participate in the oKFE-RL program to screen for cervical cancer. Patients who underwent treatment of the cervix (with preservation of the cervix) can return to the cervical cancer screening program after the end of the follow-up period.

In both situations, the required approach is that the patient should be followed up with curative intent until the end of the follow-up period. Once the follow-up period has ended, the screening approach for patients who had a total hysterectomy is that outlined in the KFE-RL, while patients who were treated with preservation of the cervix (even partial preservation) should be screened in accordance with the oKFE-RL. During the follow-up period, the approach for annual screening examinations is based on that of the KFE-RL. This makes it necessary to clarify the required follow-up strategies, and we have presented them here, based on the current guidelines. It should be noted that the terms "organized screening and screening" which are used in the guideline to refer to follow-up do not correspond to the definition used in the oKFE-RL. It needs to be emphasized that, as described above, this term refers to a curative follow-up examination. To make this clear, in the following, the term is added in brackets. 


\section{Follow-up after Hysterectomy for Benign Indications and CIN}

The S3 guideline "Prevention of Cervical Cancer" [4] includes the following statement on the issue of screening women who have had a hysterectomy (consensus-based statement no. 8.13):

"The benefit of screening in women who had a total hysterectomy has not been confirmed, irrespective of whether screening is based on cytology or HPV-testing. However, this recommendation does not extend to women with confirmed high-risk HPV infection."

The S3 guideline additionally states (consensus-based recommendation no. 8.14): "HPV-positive women who have had a total hysterectomy should continue to participate in organized screening programs" (curative follow-up examination).

Women who had a supracervical hysterectomy are also excluded. The S3 guideline states (consensus-based recommendation no. 8.15): "Women who had a supracervical hysterectomy must continue to participate in organized screening programs."

In summary, when interpreting the $\mathrm{S} 3$ guideline with regard to the screening for cervical cancer of women who are status post hysterectomy for benign indications (including $\mathrm{CIN}$ ), the guideline recommends the following:

a. According to the oKFE-RL, only those women who had a supracervical hysterectomy are entitled to continue to participate in the screening program. All other women should be screened in accordance with the annual general cancer screening guideline (KFE-RL), which does not include screening for cervical cancer.

b. Women who had a total hysterectomy and were found to be HR-HPV positive (e.g. CIN 3) should be followed up curatively. In clinical practice, two co-tests performed after 1 year respectively are recommended. If the findings are normal, this will conclude the period of curative follow-up. During and after the follow-up period, the KFE-RL (without cervical screening) will apply, as described above.

c. According to the recommendations of the S3 guideline, after surgery for CIN, curative co-testing with HPV-testing and cytology should be carried out at 6, 12 and 24 months after surgery, irrespective of the R0/R1 status (consensus-based recommendation nos. 16.1, 16.3). If any of the findings are abnormal (at least 1 positive test), then a detailed colposcopy examination should be carried out (no. 16.2), if necessary after local application of estrogen and including histological sampling (biopsy, endocervical curettage). After three negative co-test results (HPV, cytology) within the space of 2 years, the risk of an HPV-related neoplasia is low and follow-up is no longer required.

According to the oKFE-RL and the specifications of the German General Joint Committee (Gemeinsamer Bundesausschuss), the next round of screening should consist of a cytology examination performed after 12 months for women below the age of 35 and carried out together with co-testing after 3 years in women above the age of 35 years. During the period of follow-up care, the reg- ulations of the annual general cancer screening guideline (KFE-RL) without screening for cervical cancer apply.

The decision about the appropriate approach for abnormal findings detected during curative follow-up (at least 1 positive test) must be taken on an individual basis which takes the patient's prior medical history and the colposcopic findings into account, along with the results of the histological examination if a biopsy is taken or endocervical curettage is carried out.

\section{Follow-up after Hysterectomy for Cervical Cancer}

The S3 guideline on the diagnosis, treatment and follow-up of patients with cervical cancer [5] states the following with regard to the issue of screening women who had cervical cancer and a hysterectomy (p. 158; consensus-based recommendation no. 17.2):

"A mandatory examination should be carried out every 3 months for a period of 3 years, then every 6 months for a further period of 2 years. The examination should include taking the patient's medical history, a rectovaginal (sic!) examination, speculum examination and cytology."

The guideline also references HPV-testing (p. 158; consensusbased recommendation no. 17.3): “Optional examinations can be carried out if findings are clinically unremarkable (the patient is asymptomatic). These can include colposcopy, HPV-testing, vaginal ultrasound scan of the lesser pelvis and ultrasound scan of the urinary system."

Follow-up examinations must be carried out for 5 years. Cotesting with HPV-testing and cytology is particularly indicated for patients who had a trachelectomy, primary radio-chemotherapy and associated multifocal (intra-)epithelial neoplasias. The intervals between cytology examinations of the vaginal stump performed as part of follow-up after treatment for cervical cancer (p. 159; Table 19) are every 3 months for the first 3 years, then every 6 months for a further 2 years. The total follow-up time is 5 years. This guideline does not specify the intervals between HPV-tests nor how long serial HPV-testing should be carried out, and the decision should therefore be taken on an individual basis (p. 160; Table 20). Annual screening or follow-up is recommended after 5 years.

During the curative follow-up period, the recommendations of the annual general screening guideline (KFE-RL) without screening for cervical cancer apply.

\section{Follow-up after Hysterectomy for Endometrial Cancer}

As regards the follow-up of women treated for endometrial cancer, the S3 guideline on the diagnosis, treatment and follow-up of patients with endometrial cancer [6] states (p. 144; consensus-based recommendation no. 9.2): "Patients should be questioned about their medical history and be asked specific questions about symptoms and should have a clinical gynecological examination which includes a speculum examination and examination by rectovaginal palpation every 3 to 6 months in the first 3 years 
after concluding primary therapy and twice a year in the fourth and fifth year thereafter."

The S3 guideline does not recommend obtaining a cytological smear from the vaginal stump. Specifically, the guideline states (p. 146): "A cytological smear obtained from the vaginal cuff of asymptomatic patients with recurrence only results in recurrence being diagnosed in 0 to $13 \%$ of cases [390] and therefore does not appear to be a useful measure. Moreover, the use of cytological smears to follow up women with EC is not cost-effective..."

The guideline does not comment on the issue of whether women who are status post endometrial hyperplasia with and without atypia should participate in cervical cancer screening programs. Therefore, the same recommendations regarding their participation in cervical cancer screening programs apply to these women as to women without this disease (see "Follow-up examinations after hysterectomy for benign indications including CIN").

\section{Conflict of Interest}

P. H. received speaker's fees from Roche, Hologic, MSD.

\section{References}

[1] Richtlinie des Gemeinsamen Bundesausschusses über die Früherkennung von Krebserkrankungen (Krebsfrüherkennungs-Richtlinie/KFE-RL) in der Fassung vom 18. Juni 2009, veröffentlicht im Bundesanzeiger 2009, Nr. 148a, in Kraft getreten am 3. Oktober 2009, zuletzt geändert am 5. Dezember 2019, veröffentlicht im Bundesanzeiger BAnz AT 20.12.2019 B10, in Kraft getreten am 1. Januar 2020. Online: https:// www.g-ba.de/downloads/62-492-2002/KFE-RL_2019-12-05_iK-202001-01.pdf; last access: 01.05.2020
[2] Richtlinie des Gemeinsamen Bundesausschusses für organisierte Krebsfrüherkennungsprogramme oKFE-Richtlinie/oKFE-RL in der Fassung vom 19. Juli 2018, veröffentlicht im Bundesanzeiger AT 18.10.2018 B3, in Kraft getreten am 19. Oktober 2018, zuletzt geändert am 5. Dezember 2019, veröffentlicht im Bundesanzeiger BAnz AT 20.12.2019 B10, in Kraft getreten am 1. Januar 2020. Online: https://www.g-ba.de/ downloads/62-492-2001/oKFE-RL-2019-12-05-iK-2020-01-01.pdf; last access: 01.05 .2020

[3] Kassenärztliche Bundesvereinigung. Gebärmutterhalskrebs-Früherkennung. Neues organisiertes Programm im Überblick. KBV PraxisInfo Gebärmutterhalskrebs-Früherkennung/Februar 2020. Online: https:// www.kbv.de/media/sp/Praxisinfo_Fr_herkennung_Geb_ rmutterhalskrebs.pdf; last access: 01.05.2020

[4] S3-Leitlinie 'Prävention des Zervixkarzinoms' (Langversion 1.0 - Dezember 2017 AWMF-Registernummer 015/027OL. Online: https://www. leitlinienprogramm-onkologie.de/fileadmin/user_upload/Downloads/ Leitlinien/Zervixkarzinom_Praevention/LL_Pr\%c3\%a4vention_des_ Zervixkarzinoms_Langversion_1.0.pdf; last access: 01.05.2020

[5] S3-Leitlinie Diagnostik, Therapie und Nachsorge der Patientin mit Zervixkarzinom (Version 1.0 - September 2014 AWMF-Registernummer 032/033OL; Stand: 15.10.2014 (in Überarbeitung), gültig bis 31.10.2019. Online: https://www.awmf.org/uploads/tx_szleitlinien/ 032-033OLI_S3_Zervixkarzinom_2014-10.pdf; last access: 01.05.2020

[6] S3-Leitlinie Diagnostik, Therapie und Nachsorge der Patientinnen mit Endometriumkarzinom. Version 1.0 - April 2018 AWMF-Registernummer: 032/034-OL. Online: https://www.awmf.org/uploads/tx_szleitlinien/ 032-034OLI_S3_Endometriumkarzinom-Diagnostik-Therpie-Nachsorge _2018-04.pdf; last access: 01.05.2020 